\title{
THE LEVELS TO MEASURE REAL CONVERGENCE - CATCHING- UP ISSUES IN HUNGARY
}

\section{A REÁLKONVERGENCIA MÉRÉSI SZINTJEI - A FELZÁRKÓZÁS KÉRDÉSEI MAGYARORSZÁGON}

\author{
Zsuzsanna TÓTH ${ }^{\mathrm{a}}$ \\ aBudapest Business School University of Applied Sciences, Zalaegerszeg Faculty of Business \\ Administration, H-8900 Zalaegerszeg Gasparich Str. 18/A. e-mail: toth.zsuzsanna@ uni-bge.hu
}

Cite this article: Tóth, Z. (2019). The Levels to Measure Real Convergence - Catching-up Issues in Hungary. Deturope, 11(1), 74-94.

\begin{abstract}
The paper primarily focuses on Hungary's catching-up process in terms of real economics. Yet, considering that the presence or absence of real convergence can be verified in several ways, in this paper the catchingup process is analysed at three levels: I will consider how well or badly Hungary performed economically against the average performance of EU member states between 2000 and 2017 and when we can foreseeably reach such average performance level. Four groups of EU member states can be established by beta convergence analysis by taking both the initial income levels and growth rates into consideration; Hungary is also categorised accordingly. To utilise another method of categorisation and to deepen our analysis, I furthermore investigate whether Hungary belongs to the category of less developed, medium developed or developed EU countries as far as real economic indices other than GDP per capita are concerned. Finally, I analyse cross-country inequalities in Hungary. When comparisons with the other EU member states are made, it is unavoidable to discuss convergent or divergent macroeconomic trends within the EU and for this reason the paper also investigates how convergence between the EU member states can be tested and reveals the results of the related calculations.
\end{abstract}

Keywords: regional equalisation, European Union, Hungary, real convergence

\section{INTRODUCTION}

Findings of economic convergence research are available in great numbers. Such analyses and the theoretical or practical conclusions drawn from them scatter over a wide spectrum depending on the target regions and scopes of the analyses or the indicators used in the calculations, that is, the macroeconomic index or indices used as the basis for quantifying crossregion catching-up or equalisation.

This paper intends to be an addition to research findings dealing with catching-up and equalisation too. There are two arguments to justify this aim: the first is that the analyses about convergence processes among EU member states, obviously provided the right statistical methodology is applied, confirm the existence of equalisation concerning real convergence among the 28 member states. When a specific country, in our case, Hungary, is selected and we test certain macroeconomic indicators to see whether this country demonstrated catching-up or lagging tendencies over a longer period, we will, however, arrive at different findings. 
Therefore, one of the objectives for this paper is to point out that it is insufficient to analyse convergence among EU countries with only one calculation method and in aggregate form since it might yield a distorted picture of the real economic processes. To gain a more realistic picture, the analysis must be done with several macroeconomic indicators and separately for each country.

The other motivating factor behind writing this paper was that convergence analyses typically measure external catching-up, that is, whether a country is getting closer to or farther from the EU mean, or the average performance of various country groups, for example, of the eurozone or cohesion countries. Such studies ignore the internal relationships of the given country, although persistent regional cross-country inequalities may significantly hinder development and catching-up with more developed peers. So, a further objective for this paper is to highlight this shortcoming through a specific example, that of the counties of Hungary.

After the theoretical background and applied methodology is summarised, due to limitations of space, this paper discusses the changes in Hungary's real convergence in four areas only ${ }^{2}$ :

1. from the aspect of equalisation among EU member states ${ }^{3}$ based on GDP per capita figures,

2. based on the number of years required to reach the GDP per capita mean value of the European Union,

3. by categorising EU member states according to GDP per capita, employment rate and productivity,

4. cross-country equalisation based on the changes in GDP per capita figures of the various counties.

\section{THEORETICAL BACKGROUND}

\section{The complexity of convergence research}

Studies on the efficiency of European integration form a part of economic convergence research that was in the focus of analyses from the date of the first EU expansion in 1973 to that of the next large expansion in 2004.

The EU regularly publishes reports on economic, social and regional cohesion, which besides topical analyses - generally address the changes in employment, GDP per capita, export

\footnotetext{
${ }^{2}$ The limitations of space do not allow for presenting all the indicators used in the study as time series, so it is not done here.

${ }^{3}$ In my calculations I consistently ignored the data of Luxemburg. The country's outstanding data are outliers that would have distorted the results.
} 
and import within the EU, and direct capital investment in the various member states (European Commission, 2017). In international publications, convergence is interpreted as the regional equalisation of income per capita (Dauderstädt, 2014), that is, whether poorer countries grow faster than the rich ones over the analysed period. In the event the GDP per capita figures of less developed countries increase at a rate higher than those of the more developed countries, there is convergence between the analysed countries, and if no such relationship is identified between the growth rates, we can talk about divergence. Of these analyses, the theory of Barro and Sala-i-Martin is considered a ground-breaking one; it confirmed a $2 \%$ converge among the regions of Germany, Italy, the United Kingdom, France, the Netherlands, Belgium and Denmark between 1950 and 1985 with the help of GDP growth and deviation over regions (Barro - Sala-i-Martin, 1991). Using the calculation methodology developed by Barro and Salai-Martin, in a paper published in 2013, Goecke found a negative relationship between the income by capita figures of the $15 \mathrm{EU}$ member states in 1950 and the growth rates of income until 2012, therefore the neoclassical hypothesis was sustained, that the countries which were poorer at the start achieved higher growth rates. By this he proved that the more disadvantaged EU countries were able to get closer to their more developed peers in the analysed period, so convergence could be confirmed in the region. However, the decreasing trend of the difference between the income per capita of the 15 member states and the mean reached a turning point in 2007, but then it started to increase. Therefore, the author concluded that a divergent development had got started that year (Goecke, 2013). Many researchers have quantified how much the development levels of the EU member states converged by analysing GDP per capita and arrived at similar results to those of the above-mentioned two studies: Kaitila revealed betaand sigma-convergences among 27 EU member states between 1999 and $2012^{4}$. Gill and Raiser completed convergence calculations over a wider period in their work published in 2012 and confirmed sigma-convergence among the 27 member states between 1950 and 1980, and 2000 and 2010, respectively, while Cuaresma and his co-authors confirmed beta-convergence already for 28 EU member states over the period of 1995-2009 (Kaitila, 2013; Gill-Raiser, 2012; Cuaresma et al. 2012). In summary we can conclude that these studies confirmed convergence among all the member states based on the changes in their GDP per capita figures.

\footnotetext{
${ }^{4}$ Beta-convergence indicates that the poorer countries demonstrate faster economic growth than their richer peers within a region and between two dates or years. Sigma-convergence tests the reduction in the deviation of GDP per capita over different areas and a prolonged period. The specific details of the calculations are presented under Data and Methods.
} 
A further aspect to be considered when analysing convergence among EU member states is to test how much the 12 member states that joined the EU in 2004 or later were able to catch up. Vojinović, Sanjaya, and Próchniak (2009) analysed how much the ten countries joining in 2004 gained on each other and on the former 15 member states: by taking the income per capita values of the various member countries between 1992 and 2006 into consideration, they showed that beta- and sigma-convergence existed, and their calculations also incorporating the EU15 average figures furthermore confirmed that the difference between the new and old member states decreased over the analysed period.

Busch confirmed the success of the catching-up process between the countries joining the union in 2004 and the other member states by showing that, following the accession, the foreign trade, and the international flow of capital and people of the new member countries had greatly expanded by 2012. The author furthermore confirmed the acceleration of the convergence process by pointing out that during the analysed period the gross national income, gross investment volume, gross domestic consumption, R\&D expenses and net capital volume got increasingly closer to the EU15 mean (Busch, 2014).

Filipetti and Peyrache analysed the catching-up rate between 1993 and 2004 with respect to countries joining the EU in 2004 and 2007, respectively. They explained the acceleration of the catching-up of the 12 new member states with the EU15 by the closing technological gap and the improvement of productivity (Filipetti-Peyrache, 2013).

Such publications generally analysed how much the development levels of several countries got nearer to each other from the aspect of real convergence. In terms of content and methodology, the work of Diaz del Hoyo et al. can be considered as a major development as compared with the afore-cited, since they did not only analyse real convergence among the eurozone countries but also included sustainability in the analysis, pinpointing the specific positions of the various countries (Diaz del Hoyo et al., 2017).

Ever since the Maastricht Treaty was signed, the analysis of the convergence criteria set for EMU membership, that is, nominal convergence, has also become a focus of analyses. Apart from nominal and real convergence, further convergence indicators have appeared in different studies, such as the analysis of well-being, standard of living, democracy and the political institutional system (Dauderstädt, 2014).

In summary: the studies on convergence between the EU member states mainly focused on the equalisation of the income per capita figures of the countries making up the EU (real convergence), then shifted to the analysis of how much the Maastricht criteria were complied with (nominal convergence) while encompassing other selected convergence indicators. International studies are uniform in stating that there exists real convergence among EU 
member countries. Testing nominal and other, e.g. structural convergence has mainly been in the forefront of research regarding the 12 new members, and it is judged differently for each country.

When analysing the catching-up processes of countries that joined the EU in 2004 and afterwards, we can see that the analyses regard the EU countries as a homogenous set, that is, they consistently compare the performance of new entrants with that of the old members or the average performance of all the eurozone countries. This method undoubtedly yields a comprehensive view of the advancement of new entrants but fails to provide a realistic picture because of the heterogeneity of former member states. A further important proposition is that the regional inequalities within the new entrants may hinder the catching-up process, which calls for testing for cross-country convergence. In Bourdin's analysis this idea is embraced by the author considering not only external catching-up (convergence) or the lack of it (divergence) to verify income (GDP/capita) convergence or divergence within the EU but at the same time considers whether cross-country inequalities decrease or increase (Bourdin, 2015). This kind of complexity has penetrated the theories of the new economic geography, which, in terms of spatial structure, all boils down to the question whether the catching-up of a country as a whole with its European peers will be realised at the expense of regional polarisation (Nemes Nagy, 2005).

\section{The prospects of catching-up}

The primary aim for this paper is to demonstrate that the measurement of real economic convergence in a selected new member state, in our case, Hungary, can be approached from several aspects so as to gain a more realistic view of the country's performance. Nevertheless, when convergence or the catching-up of a less developed region is tested, it is also indispensable to consider the chances of such closing-up. The conclusion that can be drawn from the abovedescribed theory of Barro and Sala-i Martin justifies Jánossy's view on economic development: poorer countries are in fact able to get closer to their richer counterparts due to the spreading of technological achievements and increased productivity (Jánossy, 1975). Levitt expresses a similar thought: he holds that technological development will lead to a uniform global market, price competition will create standardised markets, which will consequently result in the convergence of prices, wages and earnings and the harmonisation of the institutional framework (Levitt, 1983).

As far as closing-up and catching-up is concerned, with respect to less developed countries and EU accession, the risks of lagging or stagnation must also be borne in mind. 
Artner and Róna have confirmed that based on the theory of optimum currency areas (Mundell,1961) the weaker status (within the eurozone) entails the risk of earnings shifting from less developed countries to more developed ones since the currency is much too strong for the less developed countries (Artner - Róna, 2012). Therefore, after joining the currency area, the less competitive countries will be forced to cope with this drawback too.

When evaluating the closing-up performance of the countries that joined the EU in 2004 and thereafter, and of Hungary among them, we must, nonetheless, bear in mind that catching up with more developed countries is a rare phenomenon. After their respective regime changes, the countries followed highly different trajectories; neither catching-up, nor lagging nor stagnation are inevitable or predestined (Csaba, 2006).

We can find only few examples of successful catching-up throughout history. Mihályi cites historical examples in his paper to demonstrate the failure of closing-up (German unification, the plans for catching-up in the Soviet Union), and by using Hungary as an example he points out that our country would persistently require 2-3 times as much extra growth to catch up with EU member states. This extra growth is hindered, however, by the indebtedness of the country's economic actors and the lack and improper allocation of the factors of production (Mihályi, 2011).

This paper does not aim to settle the argument whether closing-up is inevitable or not, or whether its absence is a natural state of matters. It rather focuses on the question whether we will gain different results with the help of country-specific multi-tier convergence analysis from those yielded by aggregate analytical methods. A further research question investigates how internal and external convergence can take place: in the case of Hungary, what are the cross-country inequalities like in the light of real economic indicators?

\section{DATA AND METHODS}

\section{The levels and dimensions of convergence}

The catching-up process of any new member state, or in our case, Hungary, can be analysed at several levels and along various dimensions: The paper is going to use the three categories published by ICEG EC (ICEG EC, 2005) to analyse the dimensions of catching-up, i.e. of nominal, real and structural convergence. Nominal convergence refers to the indicators defined by the Maastricht Treaty: inflation, budget deficit and public debt to GDP. Real convergence in short includes the indicators of economic development; in the analysis, GDP per capita, productivity and rate of employment make up this category. Structural convergence is measured by the ratio of agricultural workers, the quality of the business environment, poverty and 
household disposable earnings. The levels basically refer to spatial scope of the analysis: on the one hand, it is not sufficient to consider only whether the analysed countries are able to get closer to the economic performance of EU member states, but it is also important to see whether convergence exists within the various countries and if the given economy is getting closer to the equilibrium. On the other hand, comparison to EU countries not necessarily yields an unbiased picture, bearing in mind that difference in development can be pinpointed even among the 28 member states. In consequence, the paper is also going to group the EU countries used as a baseline and see which of these groups Hungary is nearing the most.

To analyse the differences in development of the specific country's regions beta- and sigmaconvergence calculations are applied. Nominal convergence is tested by compliance with the Maastricht criteria, while catching-up with EU member states and their subsets is analysed by describing the differences in the respective macroeconomic indicators and by clustering the four countries. Fig. 1 gives a summary of the convergence analysis.

Figure 1 The levels and dimensions of convergence

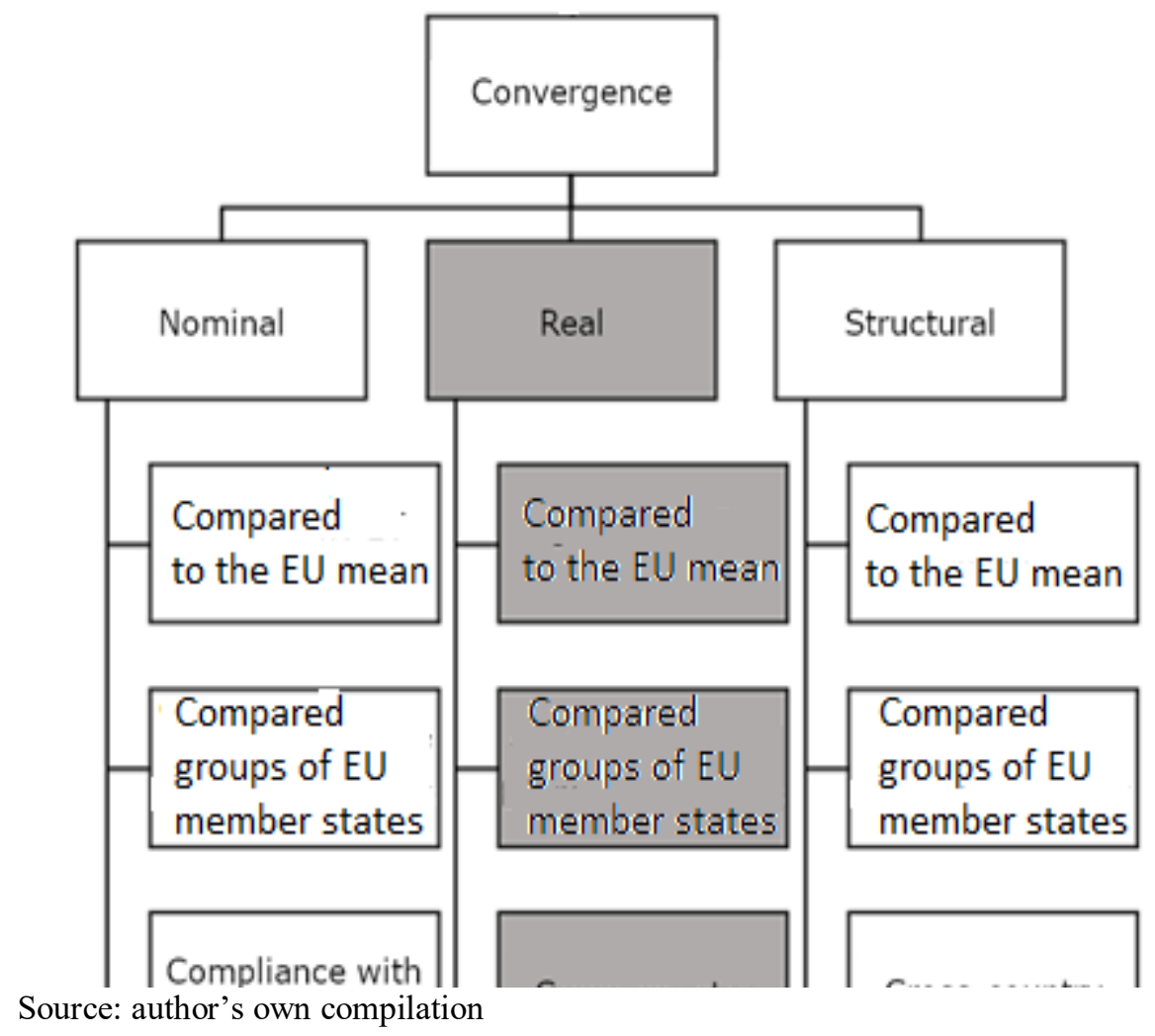

In this paper, due to limitations of space, only Hungary's real convergence is analysed based on this categorisation; see Tóth (2015) for a detailed description of the levels and dimensions used here. 


\section{The theoretical background to real convergence calculations}

When analysing the highest level in Fig. 1, Hungary's specific macroeconomic indicators between 2000 and 2017 are compared to the average figures of the EU member countries. This is done in two stages. Firstly, I verify the existence of equalisation among the EU member states between 2000 and 2017 by beta-convergence analysis. In the second stage Hungary's situation is compared to various country groups.

The first stage requires the testing of beta convergence between the EU member states. Absolute beta convergence means that the poorer countries grow faster than the rich ones. When considering the cross-sectional GDP per capita data series of several countries at times $t$ and $\mathrm{T}+\mathrm{t}$ expressed in PPS, we obtain the following regression equation:

$\gamma_{i, t, t+T}=\alpha+\beta \ln \left(y_{i, t}\right)+\varepsilon_{i, t}$

where $\gamma_{i, t, t+T}=\ln \left(\frac{y_{i, t+T}}{y_{i, t}}\right) / T$

denotes the annual average GDP growth rate of the ith economy between time $t$ and $t+T$, and $\ln (y i, t)$ is the logarithm of the income of the ith economy at time $t$. If $\beta<0$, convergence can be confirmed in the data sequence (Sala-i-Martin, 1995).

Due to the background to beta-convergence analysis, however, equalisation does not automatically mean closing-up for less developed countries, that is why the research furthermore examines how many years Hungary would need to catch up with the EU mean:

Hungary will reach the average GDP per capita of the EU member states in the $\mathrm{t}^{\text {th }}$ period, if: $G D P_{t}^{H U}=G D P_{t}^{E U}$

where:

$G D P_{t}^{H U}$ : Hungary's GDP per capita expressed in PPS in the $\mathrm{t}^{\text {th }}$ period.

$G D P_{t}^{E U}$ : Average GDP per capita figures of EU member states expressed in PPS in the $\mathrm{t}^{\text {th }}$ period.

If the average GDP growth rate of all the EU member states between period 0 and $\mathrm{t}^{\text {th }}$ is $\alpha$, and Hungary's average GDP growth rate is $\beta$, the following two equations are obtained:

$G D P_{t}^{H U}=G D P_{0}^{H U} \times(1+\beta)^{t}$

$G D P_{t}^{E U}=G D P_{0}^{E U} \times(1+\alpha)^{t}$

where:

$G D P_{0}^{H U}$ : Hungary's GDP per capita in PPS in the $0^{\text {th }}$ period

$G D P_{0}^{E U}$ : The average GDP per capita of EU member states in PPS in the $0^{\text {th }}$ period.

We are looking for the value of $t$ for which equation (2) is satisfied, i.e.:

$\frac{G D P_{t}^{H U}}{G D P_{t}^{E U}}=1$ 
After rearranging the equations applying the formulas (3) and (4) and taking their logarithm the following formula is obtained for catching-up time:

$t=\lg \frac{G D P_{0}^{E U}}{G D P_{0}^{H U}} \div \lg \frac{1+\beta}{1+\alpha}$

Using of the formula (6), and the income figures for year 2000, as the initial year, and the average growth rates in the period 2000-2017, ceteris paribus we can calculate how many years are required for catching up with the EU mean ${ }^{5}$.

The second level of testing real convergence is the comparison with country groups. The member states joining the EU in 2004 and afterwards, when deciding whether to go ahead with the accession, were motivated by the aspiration to gain similar levels of development and wellbeing to those enjoyed by former member states. The phrase 'former member states' is too general a category since the Maastricht criteria were not yet in place at the time of their accession, which would have motivated them to manage the state economy according to stricter rules. Furthermore, there were and have always been significant differences in the levels of development of the EU15 member states. There were similarly large differences between the countries joining in 2004, therefore the whole European Union was too varied both in economic and socio-political aspects to be used as a basis for comparison in its entirety. When analysing the catching-up process of new member states, and of Hungary among them, it does, in fact, matter which EU country's indicator an analysed macroeconomic indicator of the given country converges with: in terms of public debt, for instance, it is more favourable if the analysed countries approach Estonia's 7\% rate of public debt to GDP and not the Greek one, which is over $100 \%$. This is the reason for categorising EU countries and conducting the analysis with respect to the country groups.

Cluster analysis was performed to define the country groups. Clustering is the procedure in which the variables assigned to various components are the dimensions along which countries are categorised, so that the countries falling in one group would be close to each other along every variable while would fall far from the other groups (Barna \& Székelyi, 2002).

The analysis is built on hierarchical clustering (with groups created based on the distance between group means), the essence of which is that it creates clusters step by step starting out from the object until all the other objects can be incorporated in one group. For the sake of transparency, I use 3 indicators for the analysis of real convergence and standardisation between 0 and 1 is always required during the analysis. The three selected indicators are: GDP per capita, employment rate and productivity. The categorisation of EU countries according to productivity

\footnotetext{
${ }^{5}$ It is undoubtedly a simplified formula that fails to consider that growth rate of Hungary's GDP per capita is largely influenced by the EU growth rate.
} 
gives the starting point for the paper published by Novotná and Volek in 2018. The authors created three groups with a view to productivity levels in 1996: the first group consisted of the countries boasting productivity rates in excess of $100 \%$ of the EU mean. The second group included the countries with rates ranging between 50-100\% of the EU mean, and the third group comprised of those with rates below $50 \%$ of the EU mean. Their calculations put Hungary in the second group. This group was characterised by the average growth rate of productivity exceeding that of the EU until 2013 but not reaching that level since 2014 (Novotná \& Volek, 2018).

The ideas of the above-cited Bourdin and Nemes Nagy furthermore suggest that it is also important to see if there is equalisation among the regions of an economy, in this study, of Hungary, or growing income inequalities are more typical of them. This paper analyses this by the above-described beta-convergence, while sigma-convergence analysis is not presented herein.

Sala-i Martin and Barro consistently pointed out in their papers of 1990 and 1995 that betaand sigma-convergence are related: beta-convergence is a necessary but not sufficient condition of sigma-convergence (Barro \& Sala-i Martin, 1990) and (Sala-i Martin, 1995).

In connection with these convergence-theories we cannot leave out the criticism of such models either: Quah claimed that the results of the regression calculated from cross-sectional data do not confirm beta-convergence with reference to Galton's fallacy, the essence of which is that over time the extreme values will approximate the mean, therefore sigma-convergence could exist even without beta-convergence (Quah, 1993).

\section{Issues of index selection and data}

In the analyses of real convergence several indicators and macroeconomic indices can be used, for example, GDP per capita adjusted for Purchasing Power Parity, the GDP growth rate, unemployment rate, employment rate, price level, wage level and the development of other earnings. Naturally, several papers could be written on the analyses of the changes in each indicator, but considering the limitations of space, this paper tests only three indicators: GDP per capita, employment rate and productivity.

The most generally applied indicators to represent a country's economic well-being are GDP or GNI. GDP is a value-added indicator that expresses the income generated within a country's borders over a period (generally a year) both with respect to income and consumption. Although gross domestic product fails to adequately represent a nation's development indicators, the volume of available resources or the level of technological development as such, it is still suited to make the growth rates and wealth of nation states comparable. An analysis of the 
development of well-being indicators could be a separate field of any study dealing with this topic, but the primary aim of the current research is to delineate Hungary's main developmental trends and for this purpose the changes in GDP per capita figures at nominal values seems to be a fitting indicator.

The consumption side of a national economy's GDP is reflected in the market demand for products: consequently, gross domestic product is made up of consumption, corporate investment, government spending on goods and services and net export demand. The data are analysed based on the Eurostat database and by categorisation. According to the definition of the database:

- it includes the consumption of households and not-for-profit institutions;

- investments can be analysed by several statistical indicators; in this paper one of the most important ones, gross fixed capital formation is used;

- net export demand is the difference between the export and import of goods and services of the given national economy.

Among other things, the labour market conditions of the analysed country can be tested using the employment rates, i.e. the ratio of the employed to the working age population, again from the Eurostat database. Finally, the productivity indicator is taken from the AMECO database, which expresses GDP per person employed expressed in 1000 PPS.

GDP per capita figures of the counties of Hungary are used, to analyse internal convergence, such data are published by the Hungarian Central Statistical Office.

\section{RESULTS}

First of all, see whether beta-convergence is tested within the EU between 2000 and 2017, that is whether less developed countries were able to realise faster economic growth in this period than their more developed peers. Additionally, consider what country groups can be identified when illustrating beta-convergence and of such country group which are the ones that trigger and fuel convergent or divergent processes.

Afterwards, shifting the focus to Hungary's performance, the paper describes how the number of years required to catch up with EU average income has changed from year to year between 2000 and 2017 by a parallelism with the changes in the ratio of Hungarian GDP to EU mean GDP.

With the aim of deepening the analysis the results of the cluster analysis are presented based on several indicators (GDP per capita, productivity and employment rate) to show which category Hungary belongs to (less developed, medium developed or developed) in the analysed period based on these three indicators. 
Finally, to compute internal equalisation the beta-convergence on GDP per capita figures of the various counties are presented and the existence of a link between the change in GDP per capita and the value of beta is tested, based on domestic data.

\section{Convergence between EU member states}

As the first step of the analysis we must check whether there is convergence among EU member states between 2000 and 2017, or whether beta-convergence can be confirmed in this period.

The results of the calculations are presented in Fig. 2.

Figure 2 Beta convergence in the EU between 2000-2017

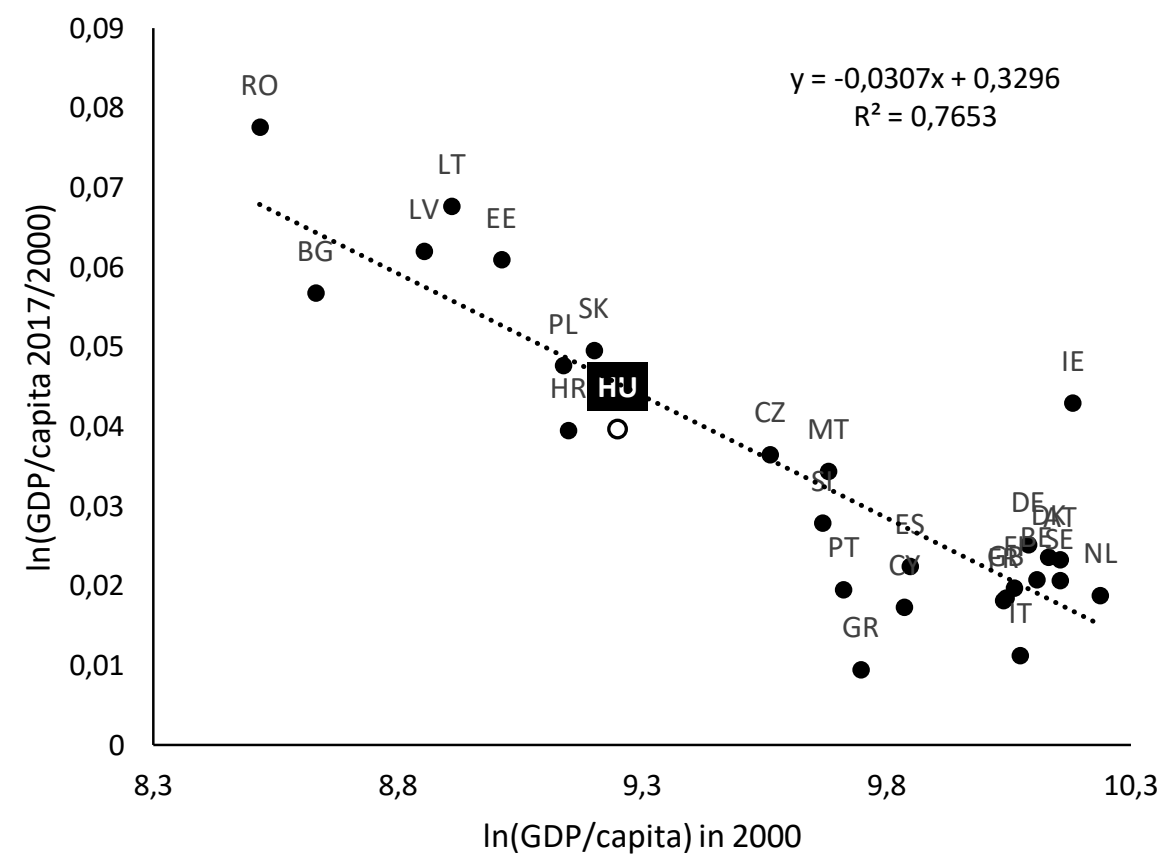

Source:author's own calculation based on Eurostat data

The vertical axis in Figure 2 shows the logarithm of the growth rate of GDP per capita between 2000 and 2017 and the horizontal axis shows the logarithm of the GDP per capita in 2000, therefore the figure illustrates equation (1). The slope of the fitted line -beta - has a negative sign (-0.0307).

Regression calculations prove that convergence can be confirmed among EU member states between 2000 and 2017 with a strong R square value and lower than 5\% significance, therefore we can state that the less developed countries grew faster in this period than their more developed peers.

To gain a more precise picture, let us divide the diagram into four parts, along the straight regression line (countries above and under the line) and along the GDP per capita median in 
2000 (the median value in our case is Portugal's income per capita). As a result, we can categorise the member states into four groups based on Figure 3:

- The first quarter includes the countries who did not show the signs of catching-up and had relatively low incomes (lagging countries that are less developed).

- The countries in the second quarter demonstrated relatively high average growth with a relatively low initial income level (countries that are less developed but are catching up).

- Category three contains the countries with relatively high incomes which demonstrated growth rates higher than the rate predicted by the regression line (developed and growing countries).

- The fourth quarter contains the countries that have relatively low growth levels with a relatively high income level (countries that are developed but still lagging).

Figure 3 Categories of countries based on beta-convergence

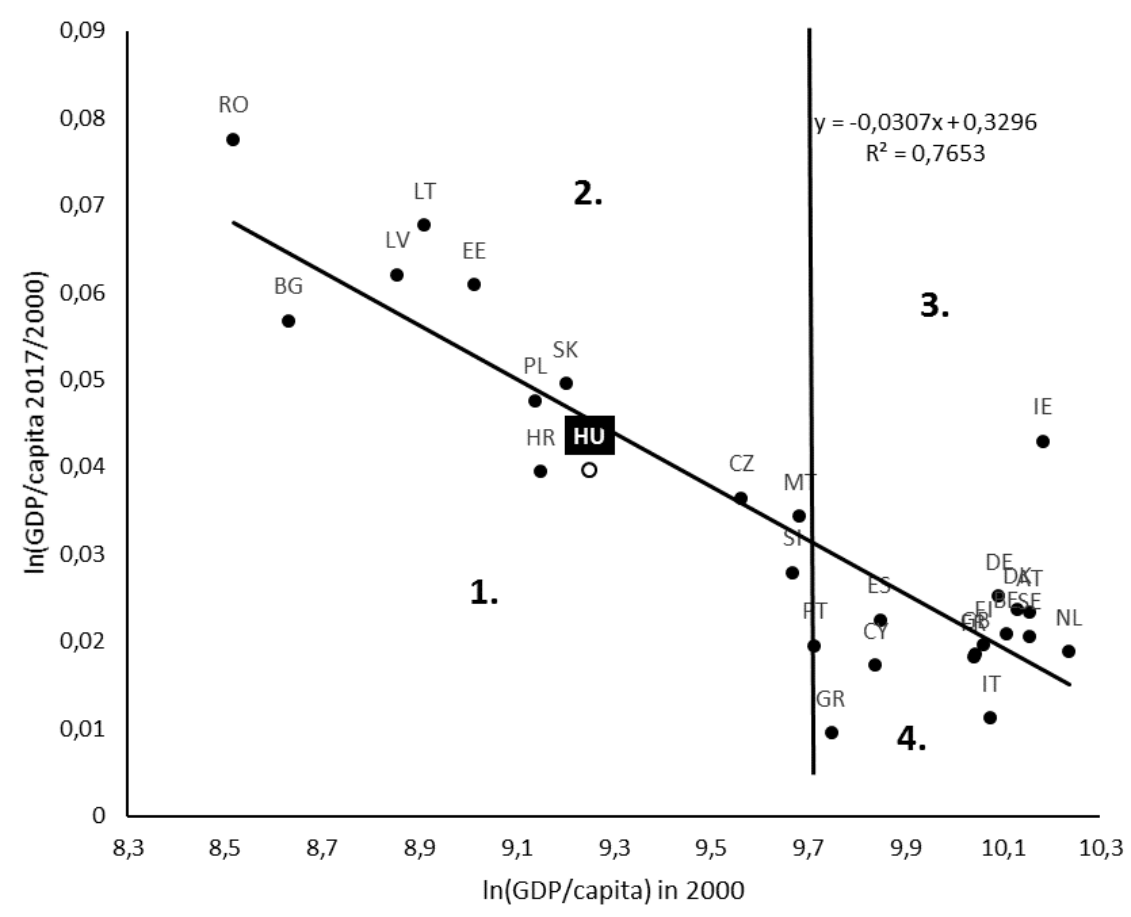

Source: author's own calculation based Eurostat data

Provided we accept this simple categorisation, we can see that the presence of betaconvergence is mostly justified by the countries in quarters 2 and 4, while the countries in quarters 1 and 3 hinder the process of equalisation.

Before completing further analyses, it is important to note that Hungary is in the first quarter during the analysed period along with Poland, Slovenia, Croatia and Bulgaria, that is among less developed countries that are lagging behind their peers. 


\section{Hungary's catching-up with the EU mean}

In the following section, we are going to see how the number of years required to close on the EU mean changed between 2000 and 2017 by considering the EU average growth rate and that of Hungary using the calculation method presented above. Also included are percentages to illustrate the ratio of domestic GDP (PPS) per capita to EU average GDP per capita figures in the different years.

Figure 4 The number of years needed for catching-up, and changes in the ratio of Hungary's GDP per capita to the EU mean

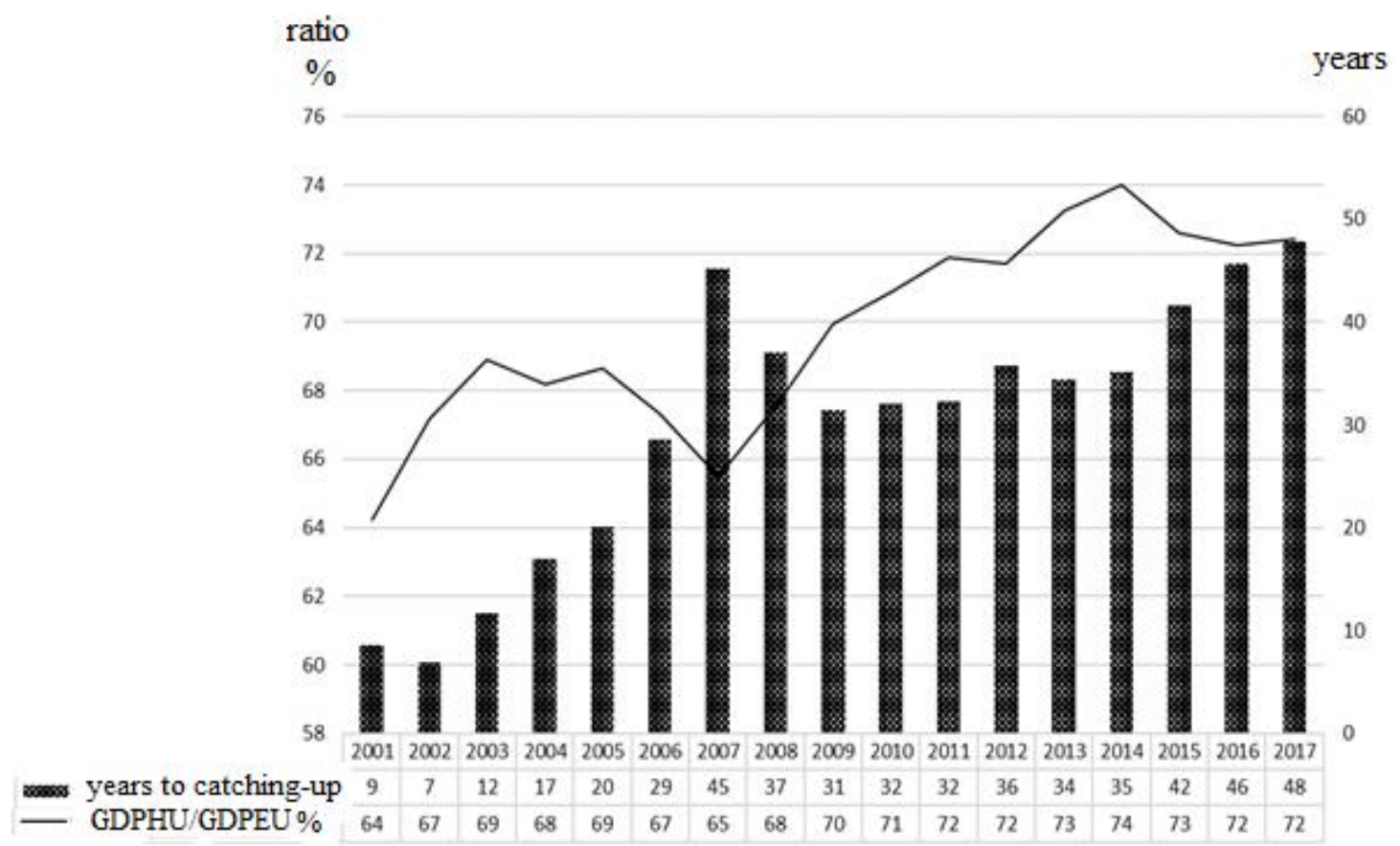

Source: author's own calculation based on Eurostat data

In the ideal case, the ratio of GDP per capita should demonstrate a constant increase and the number of catching-up years a decrease. As opposed to this, we can see that between 2001 and 2007 the number of years required to catch up with the estimated EU mean grew increasingly, while domestic GDP showed a downward trend after a short span of convergence. The figure highlights the fact that our country had already shown the signs of recession well before the global crisis, as early as 2005, and this drop had become salient in comparison with EU member states by 2007: the number of catching-up years was strikingly high that year, while GDP per capita fell back to $66 \%$ of the EU mean. In post-crisis years, right until 2014 , we can see that while the catching-up time stabilised around 35 years, there was a gradual convergence in GDP 
per capita. Since 2015 this trend has reversed; the time required for catching-up is increasing again, although at a slow pace, while we can observe that income levels fall behind or stagnate.

\section{Hungary's real economic position among EU member states}

Below, Hungary's real convergence is tested by creating groups. In order to gain a more realistic insight into Hungary's real economic position, not only the GDP per capita figures are considered, but also two other indicators. We are going to demonstrate which group of EU countries Hungary belongs to in terms of development levels (low, medium or high) based on the employment and productivity levels too. The results of the calculations are presented in Table 1, while Tab. 2 shows the group averages for the country groups created by cluster analysis based on the employment rate, GDP per capita and productivity data between 2000 and 2017. The numbers in parentheses after country names indicate the country groups defined in Fig. 2, i.e.:

(1): poor and lagging countries

(2): poor but catching up countries

(3): rich countries that develop further

(4): rich but lagging countries

Table 1 Country groups based on real economic position between 2000 and 2017

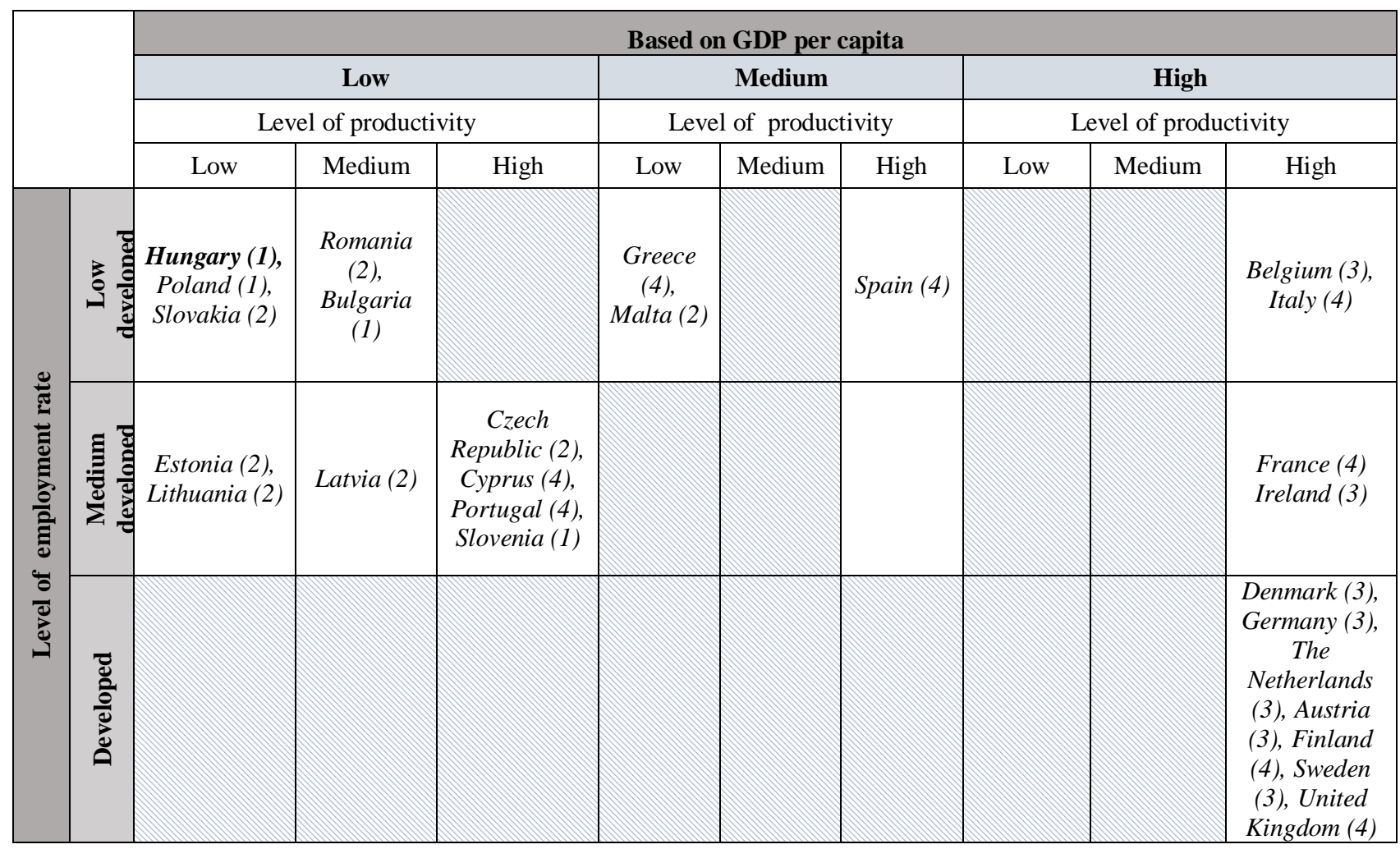

Source: own calculation based on Eurostat and AMECO data 
Table 2 Average employment rates, GDP per capita figures and productivity levels between 2000 and 2017 in the various development groups

\begin{tabular}{|l|c|c|c|c|c|c|}
\hline \multirow{2}{*}{\multicolumn{1}{|c}{ Country groups }} & \multicolumn{2}{c}{$\begin{array}{c}\text { Employment } \\
\text { rate }\end{array}$} & \multicolumn{2}{|c|}{ GDP per capita } & \multicolumn{2}{c|}{ Productivity } \\
\cline { 2 - 7 } & Mean (\%) & $\mathbf{N}$ & $\begin{array}{c}\text { Mean } \\
\text { (PPS) }\end{array}$ & $\mathbf{N}$ & $\begin{array}{c}\text { Mean (thousand } \\
\text { PPS) }\end{array}$ & N \\
\hline $\begin{array}{l}\text { low level of development } \\
\text { medium level of } \\
\text { development }\end{array}$ & 58.40 & 11 & 14424.48 & 9 & 26.56 & 3 \\
\hline high level of development & 65.30 & 9 & 21542.86 & 7 & 42.56 & 1 \\
\hline
\end{tabular}

Source: own calculation based on Eurostat and AMECO data

In the analysed period, the cluster analysis identified clearly separate country groups bearing significant differences. Hungary is among the countries with low levels of development in all the three respects. In the group of countries with low development levels, we can find countries (Romania and Bulgaria) that persistently have higher productivity levels, which proves that relatively low employment and income levels may be coupled with higher levels of productivity. These calculations do not contradict those of Novotná and Volek: the group of developed countries coincides with their first group that shows higher productivity levels than the EU mean. There are differences between the countries in groups 2 and 3 (in this paper, the groups of countries with medium and high development levels), which might result from the fact, that the authors categorised the countries based on their performance in 1996 as the base year. However, they also pointed out in their paper that the growth rate of the productivity of group 2 countries had failed to reach the EU mean since 2014, even taking a significant plunge during the years of the crisis. The growth rate of this group's productivity currently stands at the 1997 level, consequently, in the longer run, seen dynamically, we may rightly assume that the original categorisation (of 1996) has changed.

\section{Internal equalisation}

In the following section the above-described beta convergence indicator is used to analyse internal equalisation. The research results described in the relevant literature typically calculate the beta value between two dates (for example 2000 and 2017), or they might cut a longer period into two or three time segments specified by major economic events (e.g. between the year of EU accession and of the economic crisis, and the subsequent period). Here I am going to assess the changes in beta based on the GDP per capita figures of the Hungarian counties and considering year 2000 as the base year. Figure 5 shows the slope of the linear regression line illustrating the relationship between the logarithm of GDP per capita of the base year and the logarithm of average GDP growth rate between 2000 and 2002, then between 2000 and 2003 etc. 
Figure 5 Changes in beta values in Hungary

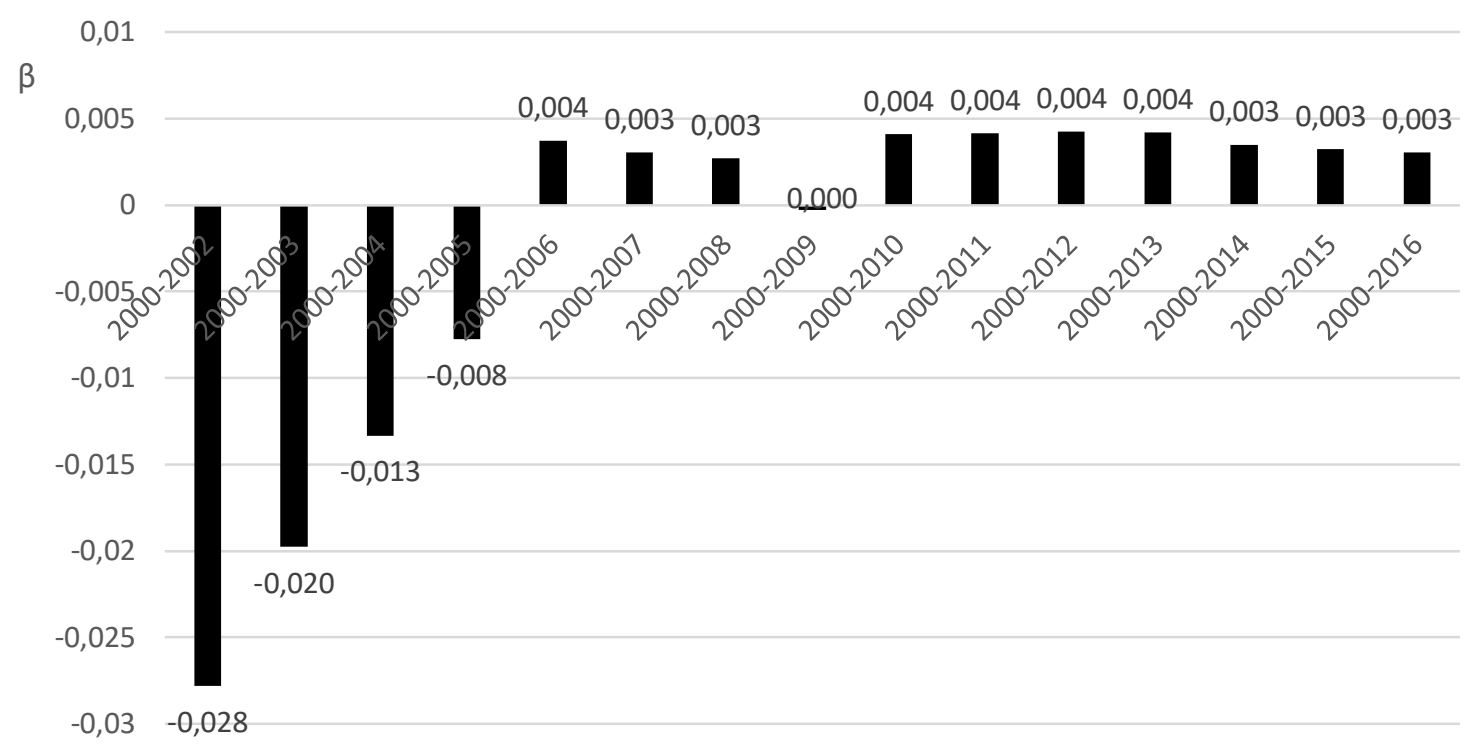

Source: author's own calculation based on HCSI data

Convergence between counties can be confirmed if the beta values are negative. Figure 5 confirms this to be true for every year between 2000 and 2005, although with a decreasing equalisation rate. The years following the EU accession had already been characterised by divergence, which was cut short by the crisis, and since 2010 the beta has been positive every year, and the differences in levels of development between counties have proved persistent ever since. Beta convergence analyses can be applied to Hungary in a somewhat limited way, due to the fact, that there is a positively significant $(\mathrm{p}<0.05)$ relationship with high $\mathrm{R}$-square values between GDP per capita and the beta convergence indicator as shown in Fig. 6 .

Figure 6 Relationship between GDP per capita and beta

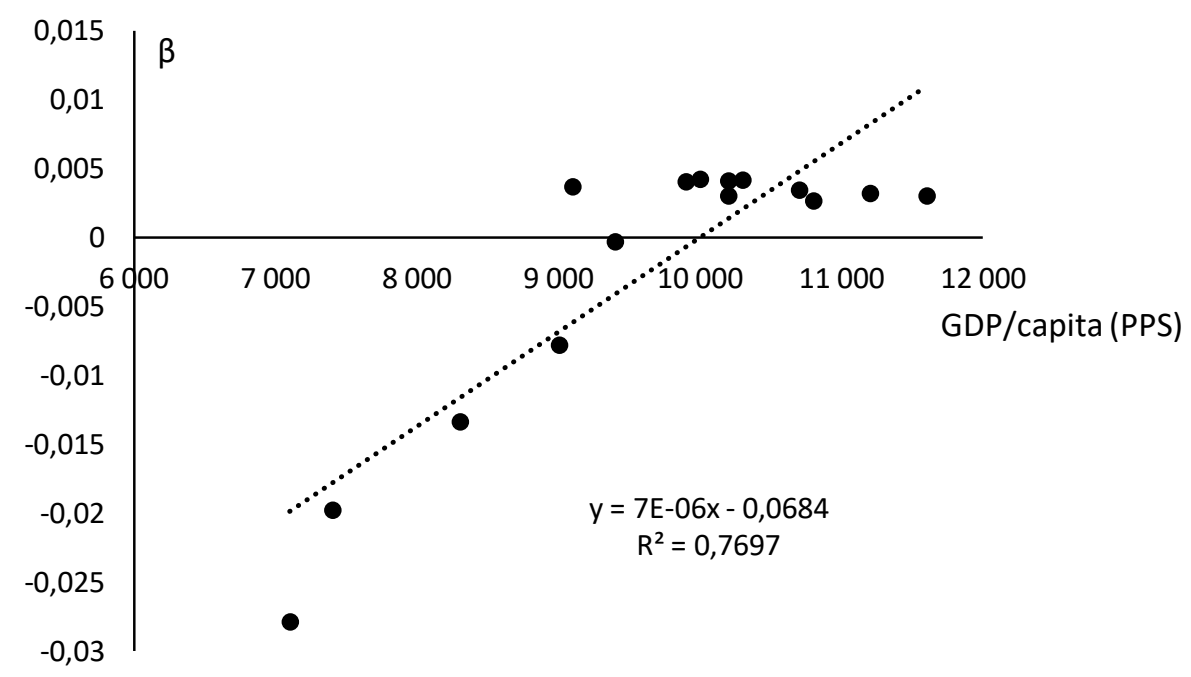

Source:author's own calculation based on HCSI and Eurostat data 
This positive relationship suggests that in the period since 2000, as incomes have increased, so has the level of inequality. Even if we do not totally accept this opinion in terms of statistics because of the low number of data (18 years), Figure 6 still suggests that we can assign a negative beta value to low income levels while for GDP values over 9000 the beta values are positive, what's more, nearly constant, which do not change, which suggests that inequalities are 'cast in stone'.

\section{DISCUSSION}

Analyses and publications confirm equalisation among EU member states in terms of real convergence over several periods and between different country groups. My calculations do not refute them: beta convergence can in fact be confirmed among the incomes of EU member states. Still, we must not forget that certain countries do not take part in the shift towards equality. There are states that fall behind their peers even despite their poorer initial positions. Hungary is also one of such lagging countries.

Catching-up as an aim goading the Hungarian economy seems unreachable both considering the current results and their trends. While GDP per capita altogether has been approaching the EU mean since the beginning of the 2000 s, rising from the initial $60 \%$ to over $70 \%$, this performance has still proved insufficient for the catching-up years to diminish in number. The estimated catching-up period of 35-50 years is currently increasing and, consequently, reaching the EU mean income levels seems to be a dream for Hungary for the time being.

This stagnating and deteriorating trend is supported and partly explained by the fact, that Hungary had belonged to the category of least developed countries already in the period preceding the accession and has persistently belonged there ever since in terms of changes in incomes, labour market conditions and efficiency. The concurrently low levels of these factors are clearly a sign. The long-term catching-up opportunities of a country with low income and employment levels are largely improved if its productivity is high or at least shows a growing trend. Romania, for instance, shows better efficiency ratios in the categorisation than Hungary, which will, in the long term, mean better competitiveness and facilitates Romania's catchingup at a higher pace. However, the improvement in the relative position of the other countries will reduce Hungary's chances of catching-up, and will consequently increase the number of catching-up years.

There are numerous reasons for Hungary's lagging behind; one of the possible explanations is that regional inequalities are getting fixed. While in the pre-accession period income levels were typically equalising among domestic counties, since the EU accession, the inequalities 
have become more pronounced: the 'poor' counties lag behind while the more developed regions keep developing. It is an alarming negative phenomenon that GDP growth made income inequalities more striking in the analysed period, which implies that the extra income, let it be generated with EU support or by factors traditionally enhancing development, will cause lagging regions to drift more and more towards the periphery.

\section{CONCLUSION}

Considering all the points presented in this paper we can state that it is not sufficient to confirm beta-convergence to adequately analyse the differences among EU member countries. This convergence indicator is a fitting basis for analysing catching-up, but we must also consider where the given member states are in relation to the resulting linear regression line.

The presented beta convergence and cluster analyses of all the EU member countries over the analysed period may seem contradictory at first glance: while beta convergence confirms equalisation among the member states, the results of the cluster analysis separate the countries into categories according to their development levels. Yet, the countries shown in Figure 3 and categorised in Table 1 match, which means that the countries slowing down or even hindering equalisation are naturally present in the convergence process (the richer and developing, and the less developed and lagging countries) as well as those countries that act as motive forces in this process.

A further conclusion is that it is also important to consider the catching-up processes of the various countries one by one. It is not enough to focus only on the actual indicator value as the percentage of the EU. The chances of catching-up must be analysed at several levels and with various methods to gain a more precise picture and understand the underlying reasons.

In closure, to answer the question posed at the beginning of the paper whether Hungary is going to catch up with its more developed peers at the expense of cross-country inequalities: the findings suggest that Hungary's catching-up has become doubtful with the ever more pronounced cross-country inequalities.

\section{Acknowledgement}

This paper has been prepared in the framework of the research workshop 'Micro and macroeconomic processes in the past and present' no. I./2018 established with funding provided by the Research Fund of the Budapest Business School University of Applied Sciences. Let me express my special gratitude to the members of the workshop, my colleagues, for their useful advice, recommendations and additions. 


\section{REFERENCES}

Artner, A., \& Róna, P. (2012). Eurosz(k)epszis: Az optimális valutaövezet elmélete és az euró gyakorlata; Köz-Gazdaság Volume VII, Issue 1 (February) pp. 83-102.

Barna, I., \& Székelyi, M. (2002). Túlélökészlet az SPSS-hez; Typotex Kiadó, Budapest

Barro, R. J., \&Sala-i-Martin, X. (1990). Economic Growth and Convergence across the United States; National Bureau of Economic Research, Working Paper No. 3419, Cambridge

Barro, R. J., \& Sala-i-Martin, X. (1991). Convergence Across States and Regions; Brookings papers on Economic Activity No.1. Retrieved from: http://www.brookings.edu/ /media/Projects/BPEA/1991\%201/1991a_bpea_barro_salai martin_blanchard_hall.PDF, 27 May 2015 pp. 107-182.

Bourdin, S. (2015). National and regional trajectories of convergence and economic integration in Central and Eastern Europe; The Canadian journal of regional science - La revue canadienne des sciences régionales 38(1/3), December 2015 pp. 55-63.

Busch, B. (2014). Zehn Jahre Osterweiterung der Europäischen Union. iw-Trends 1/2014; Retrieved from: http://www.iwkoeln.de/_storage/asset/161537/storage/master/file/4353264/download/T R-1-2014-Busch.pdf, 29 May 2015

Csaba, L. (2006). A fölemelkedö Európa. Akadémia Kiadó, Budapest

Cuaresma, J. C., Havettová, M., \& Lábaj, M. (2012). Income Convergence Prospects in Europe: Assessing the Role of Human Capital Dynamics; Department of Economics Working Paper No. 143, Wirtschafts Universität Wien, July 2012 Retrieved from: https://epub.wu.ac.at/3597/2/wp143.pdf, 7 May 2015

Dauderstädt, M. (2014). Convergence in Crisis - European Integration in Jeopardy; Friedrich Ebert Stiftung, International Policy Analysis. Retrieved from: http://library.fes.de/pdffiles/id/ipa/11001.pdf, 6 May 2015

Diaz del H. J. L., Dorrucci, E., Heinz. F. F., \& Muzikarova, S. (2017). Real convergence in the euro area: a long-term perspective. Occasional Paper Series No 203/December 2017, European Central Bank

European Commission (2017). My Region, My Europe Our Future. Seventh report on economic, social and territorial cohesion. Report from the Commission; Brussels. Retrieved from: http://ec.europa.eu/regional_policy/sources/docoffic/official/reports/cohesion7/short_7c r_en.pdf, 5 May 2018

Filipetti, A., \& Peyrache, A. (2013). Is the Convergence Party Over? Labour Productivity and the Technology Gap in the EU. Journal of Common Market Studies, 51, 1006-1022.

Gill, S. I., \& Raiser, M. (2012). Europe's Golden Growth - Restoring the Lustre of the European Economic Model; The World Bank, Washington 2012. Retrieved from: http://wwwwds.worldbank.org/external/default/WDSContentServer/WDSP/IB/

2012/04/20/000386194_20120420032146/Rendered/PDF/681680PUB0EPI0040190201 20Box367902B.pdf 7 May 2015

Goecke, H. (2013). Europa driftet auseinander. Ist dies das Ende der realwirtschaftlichen Konvergenz? iw-Trends, Köln. Retrieved from: http://www.iwkoeln.de/_storage/asset/138521/storage/master/file/4183921/download/T R-4-2013-Goecke.pdf, 7 May 2015. pp. 67-79.

ICEG EC (2005). ICEG Európai Központ és Világgazdaság Az új tagállamok konvergenciaindexe 2005/1 jelentés. Retrieved from: http://www.icegmemo.hu/hun/_docs/publikaciok/egyeb/konvergencia05_1.pdf, 11 June 2014

Jánossy, F. (1975). A gazdasági fejlődés trendvonaláról. Magvető Könyvkiadó, Budapest. 
Kaitila, V. (2013). Convergence, Income Distribution, and the Economic Crisis in Europe; Etla Working Papers, No. 14. 17 June 2013. Retrieved from: http://www.etla.fi/wpcontent/uploads/ETLA-Working-Papers-14.pdf, 7 May 2015

Levitt, T. (1983). The Globalisation of Markets. Harvard Business Review, 25(3), 92-102.

Mihályi, P. (2011). Utolérési kísérletek Magyarországon, 1870 - 2030. Magyar Tudományos Akadémia, Közgazdaságtudományi Intézet; Mühelytanulmányok MT-DP 2011/1. Retrieved from: http://econ.core.hu/file/download/mtdp/MTDP1101.pdf, 10 May 2015

Mundell, R. A. (1961). A Theory of Optimum Currency Areas; The American Economic Review, 51(4), 657-665.

Nemes Nagy, J. (2005). Fordulatra várva - a regionális egyenlőtlenségek hullámai In: DövényiSchweizer (ed.). A földrajz dimenziói; Budapest MTA FKI, pp. 141-158.

Novotná, M., \& Volek, T. (2018). Efficiency of Production Factors in the EU. Deturope, 10(2), $147-168$

Quah, Danny T. (1993). Galton's Fallacy and Test of the Convergence Hypothesis; Scandinavian Journal of Economics, 95(1), 427-443.

Sala-i-Martin, X. (1995). The Classical Approach to Convergence Analyses; The Economic Journal, 106(437), 1019-1036. Yale University and Universitat Pompeu Fabra.

Tóth, Z. (2015). A konvergencia mérhetősége és megvalósulása az EU-ban a visegrádi négyek példáján keresztül in György Juhász: A komáromi Selye János Egyetem 2015-ös „Innováció és kreativitás az oktatásban és a tudományban" Nemzetközi Tudományos Konferenciájának tanulmánykötete. pp. 148-164.

Vojinović, B., Sanjaya, A., \& Próchniak, M. (2009). Convergence Analyses among the Ten European Transition Economies; Hitotsubashi Journal of Economics 50. Retrieved from: http://eprints.lib.hokudai.ac.jp/dspace/bitstream/2115/42820/2/sanjaya_HJE50.pdf, 9 May 2015. pp. 17-35. 